\title{
Antibody generation and immunoassay development in diverse formats for pyrimethanil specific and sensitive analysis
}

\author{
Josep V. Mercader, ${ }^{a}$ Francesc A. Esteve-Turrillas, ${ }^{a}$ Consuelo Agulló, ${ }^{b}$ Antonio Abad-Somovilla ${ }^{b}$ and \\ Antonio Abad-Fuentes *a \\ ${ }_{5}$ Received (in $\left.X X X, X X X\right)$ Xth $X X X X X X X X X 20 X X$, Accepted $X t h X X X X X X X X X 20 X X$ \\ DOI: $10.1039 / b 000000 x$
}

Immunochemical techniques are complementary tools to modern analytical requirements. These methods rely on the production of immunoreagents with adequate binding properties. In the present study, a rationally-designed functionalized derivative of pyrimethanil - a modern anilinopyrimidine fungicide -

10 was synthesized in order to generate for the first time high-affinity and selective antibodies to this xenobiotic. A single coupling procedure - based on hapten activation using $N, N$ '-disuccinimidyl carbonate and purification of the active ester - was followed to prepare both immunizing and assay conjugates. Polyclonal antibodies were produced and characterized by enzyme-linked immunosorbent assay (ELISA) in four alternative formats: one indirect and three direct competitive procedures. The 15 selected immunoassay displayed a limit of detection of $0.024 \mu \mathrm{g} \mathrm{L}^{-1}$, far lower than the official maximum residue limits and close similar to the sensitivity of regular instrumental assays. This ELISA was shown to be robust to buffer changes and tolerant to the presence of little amounts of methanol, ethanol and acetonitrile. Finally, the developed assay was applied to the analysis of pyrimethanil in carrot juice samples, and a limit of quantification of $0.040 \mathrm{mg} \mathrm{L}^{-1}$ was determined.

\section{${ }_{20}$ Introduction}

The development and application of bioanalytical techniques to xenobiotic determination has meant a step forward to attaining more rapid, simple and inexpensive methodologies for new or alternative analytical applications, such as on-site environmental 25 monitoring, food safety crises and private quality controls. Particularly, immunochemical assays, which are based on the specific antibody-antigen interaction, have been developed for the analysis of a large list of chemical substances, including antibiotics, $^{1,2}$ hormones $^{3}$, drugs of abuse, ${ }^{4}$ mycotoxins, ${ }^{5,6}$ 30 pesticides, ${ }^{7,8}$ packaging components, ${ }^{9,10}$ industrial contaminants, ${ }^{11}$ etc. Due to the haptenic character of those small chemical compounds, immunoassays need to be performed in competitive mode. The most common immunoanalytical method is the enzyme-linked immunosorbent assay (ELISA) which can be 35 arranged in different formats. At least, three immunoreagents are required in order to develop a competitive ELISA; that is, the immunizing bioconjugate, the antibody and the assay bioconjugate. Hapten design and antibody generation are key steps for immunoassay development. Assay sensitivity directly

40 depends on the affinity of the antibody towards the target analyte, and linker derivatization site strongly determines antibody specificity.

Pyrimethanil is a fungicide belonging to the anilinopyrimidine class of pesticides that also includes cyprodinil and mepanipyrim

${ }_{45}$ (Fig. 1). It inhibits the secretion of hydrolytic enzymes that are required during the infection process, so it blocks the ability of fungi to degrade and digest the infected tissues, thus stopping

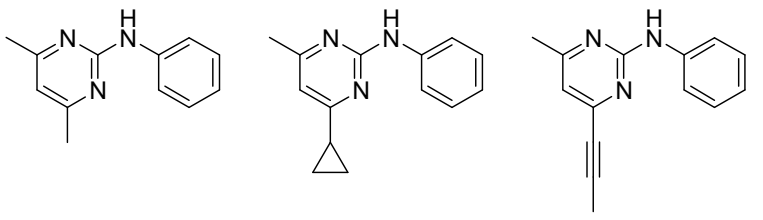

Fig. 1. Chemical structures of the three anilinopyrimidine fungicides. From left to right: pyrimethanil, cyprodinil and mepanipyrim.

penetration and development of the disease, even though inhibition of methionine biosynthesis in fungal cells has also been 50 suggested. ${ }^{12}$ Pyrimethanil has low acute toxicity in mammals, however long-term studies showed certain toxicity in mice, rats, dogs and aquatic organisms. It was found that very little metabolism occurs in plants, so the major residue for plant commodities has been defined as the pesticide itself. ${ }^{13}$ This 55 fungicide was incorporated in 2006 into Annex I of the European Council Directive $91 / 414 /$ EEC, ${ }^{14}$ listing the approved active substances for plant protection in the EU. It is extensively used to control fungal attacks on ornamentals, fruits and vegetables, including roots and tubers, and consequently residues of 60 pyrimethanil are frequently found in foodstuffs. ${ }^{15}$ Maximum residue limits of this xenobiotic have been established in the EU at $10 \mathrm{mg} \mathrm{kg}^{-1}$ for citrus, $5 \mathrm{mg} \mathrm{kg}^{-1}$ for most fruits and $1 \mathrm{mg} \mathrm{kg}^{-1}$ for most vegetables. ${ }^{16}$

Regular analytical procedures for pyrimethanil consist of ${ }_{65}$ organic solvent extraction (acetone or methanol), clean-up and analysis by either gas chromatography (GC), with a mass spectrometer detector $(\mathrm{m} / \mathrm{z} 198)$, or by high-performance liquid 


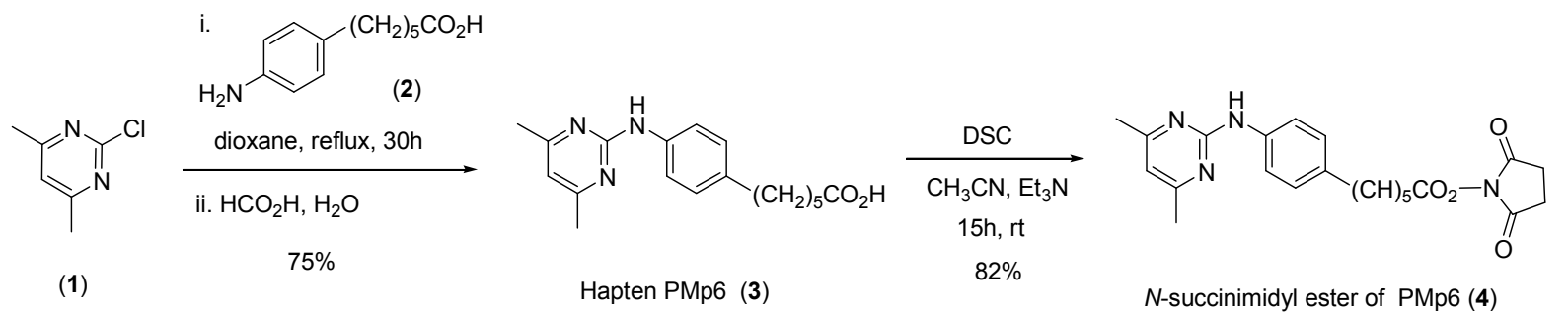

Fig. 2. Schematic representation of the synthesis and activation of hapten PMp6. DSC stands for $N, N^{\prime}$-disuccinimidyl carbonate.

chromatography (HPLC) with an ultraviolet detector. Limits of quantification between 0.02 and $0.05 \mathrm{mg} \mathrm{kg}^{-1}$ were demonstrated for fruits and vegetables by such methods. ${ }^{17}$ Those are highly powerful techniques for surveillance and control programs due to 5 their low limits of detection and high capacity for multiresidue analysis.

Nowadays, scientific analytical research is going on in order to develop new analytical methodologies for pyrimethanil, and several articles have been published recently concerning 10 instrumental methods. ${ }^{18-20}$ However, to our knowledge, no articles have been published so far regarding the production of immunoreagents and the development of immunoassays for this xenobiotic. The aim of our study was the synthesis of a functionalized derivative of pyrimethanil suitable for generating 15 high-affinity and selective antibodies for this compound. Moreover, these antibodies and bioconjugates were applied to the development of sensitive immunoassays for pyrimethanil analysis.

\section{Experimental}

\section{${ }_{20}$ Chemicals and instruments}

Pyrimethanil [N-(4,6-dimethylpyrimidin-2-yl)aniline $]$ (CAS registry number 53112-28-0; MW $199.25 \mathrm{~g} / \mathrm{mol}$ ) and other fungicide standards were purchased either from Riedel-de-Haën (Selzee, Germany) or Dr. Ehrenstorfer (Augsburg, Germany). ${ }_{25}$ Pesticide standards were prepared as concentrated solutions in anhydrous $\mathrm{N}, \mathrm{N}$-dimethylformamide (DMF) and were kept at $-20{ }^{\circ} \mathrm{C}$ in amber glass vials. 6-(4-Aminophenyl)hexanoic acid (2) was prepared from 1-iodo-4-nitrobenzene and hex-5-ynoic acid. ${ }^{21}$ Other reagents were acquired from commercial sources and used 30 without purification. Reactions were monitored with the aid of thin-layer chromatography using $0.25 \mathrm{~mm}$ pre-coated silica gel plates. Visualization was carried out with UV light and a $50 \%$ (v/v) aqueous ceric or ammonium molybdate solution. Flash column chromatography was carried out with the indicated 35 solvents on silica gel 60 (particle size $0.040-0.063 \mathrm{~mm}$ ). All melting points were determined using a Kofler hot-stage apparatus and are uncorrected. NMR spectra were recorded on a Bruker AC-300 spectrometer $(300.13 \mathrm{MHz}$ for $1 \mathrm{H}$ and 75.47 $\mathrm{MHz}$ for $13 \mathrm{C}$ ), and they were referenced to residual solvent 40 protons in the ${ }^{1} \mathrm{H}$ NMR spectra (7.15 and 2.50 ppm for $\mathrm{C}_{6} \mathrm{D}_{6}$ and DMSO- $\mathrm{d}_{6}$, respectively) and to solvent carbons in the ${ }^{13} \mathrm{C} N M R$ spectra $\left(128.0\right.$ and $39.43 \mathrm{ppm}$ for $\mathrm{C}_{6} \mathrm{D}_{6}$ and $\mathrm{DMSO}-\mathrm{d}_{6}$, respectively). Infrared (IR) spectra were measured using a Nicolet Avatar 320 spectrometer. Mass spectra (MS) and high-resolution 45 mass spectra (HRMS) were recorded in the electron impact mode (EI, $70 \mathrm{eV}$ ) using a Micromass VG Autospec spectrometer. The most stable conformation of pyrimethanil was calculated using CONFLEX with MM3 molecular mechanics to systematically search for low-energy conformers, followed by geometry 50 optimization in MOPAC using PM3 parameters (CAChe WorkSystem Pro, version 7.5.0.85).

Horseradish peroxidase (HRP), ovalbumin (OVA) and $o$-phenylenediamine were purchased from Sigma-Aldrich (Madrid, Spain). Bovine serum albumin (BSA) fraction V was ${ }_{55}$ purchased from Roche Applied Science (Mannheim, Germany). Sephadex G-25 HiTrap Desalting columns from GE Healthcare (Uppsala, Sweden) were used for conjugate purification. Capture goat anti-rabbit immunoglobulin (GAR) polyclonal antibody was acquired to Rockland Immunochemicals (Gilberstville, PA, USA) 60 and goat anti-rabbit immunoglobulin polyclonal antibody conjugated to peroxidase (GAR-HRP) was from BioRad (Hercules, CA, USA). Foetal bovine serum (FBS) and Freund's adjuvants were from Sigma-Aldrich (Madrid, Spain). Costar flatbottom high-binding 96-well polystyrene ELISA plates were ${ }_{65}$ from Corning (Corning, NY, USA). UV-visible spectra and ELISA absorbances were read with a PowerWave HT from BioTek Instruments (Winooski, VT, USA). Microwells were washed with an ELx405 microplate washer also from BioTek Instruments.

\section{${ }_{70}$ Buffers and solutions}

a) $\mathrm{CB}, 50 \mathrm{mM}$ sodium carbonate-bicarbonate buffer, $\mathrm{pH} 9.6$; b) enzyme substrate buffer, $25 \mathrm{mM}$ sodium citrate and $62 \mathrm{mM}$ sodium phosphate buffer, $\mathrm{pH} 5.4$; c) PB, $100 \mathrm{mM}$ sodium phosphate buffer, $\mathrm{pH} 7.4$; d) PBS, $10 \mathrm{mM}$ sodium phosphate 75 buffer, pH 7.4, with $140 \mathrm{mM} \mathrm{NaCl}$; e) PBST, PBS containing $0.05 \%(\mathrm{v} / \mathrm{v})$ Tween 20 ; and $\mathrm{f}$ ) washing solution, $150 \mathrm{mM} \mathrm{NaCl}$ containing $0.05 \%(\mathrm{v} / \mathrm{v})$ Tween 20 .

\section{Hapten preparation, activation and purification}

Hapten PMp6 [6-(4-(4,6-dimethylpyrimidin-2-ylamino)phenyl) 80 hexanoic acid (3)] was prepared as schematized in Fig. 2. A mixture of 2-chloro-4,6-dimethylpyrimidine (1, $142.8 \mathrm{mg}, 1.00$ $\mathrm{mmol}$ ) and 6-(4-aminophenyl)hexanoic acid (2, $207 \mathrm{mg}, 1.00$ $\mathrm{mmol})$ in anhydrous 1,4-dioxane $(5 \mathrm{~mL})$ was heated at reflux with stirring for $30 \mathrm{~h}$ under nitrogen atmosphere. After this time, 85 the mixture was cooled to room temperature (rt) and concentrated to dryness under reduced pressure. The obtained residue was dissolved in approximately $0.5 \mathrm{~mL}$ of formic acid and the product precipitated by slow addition of water (approximately $3 \mathrm{~mL}$ ). The precipitate was filtered off, washed several times with cold water 90 and dried under vacuum to afford hapten PMp6 (3) as a white solid (235 mg, 75\%). Mp. 180-183 ${ }^{\circ} \mathrm{C}$ (crystallized from DMSO$\left.\mathrm{H}_{2} \mathrm{O}\right) ;{ }^{1} \mathrm{H}$ NMR (300 MHz, DMSO-d $\left.{ }_{6}\right) \delta(\mathrm{ppm}) 11.98(1 \mathrm{H}$, br s, 
COOH), 9.33 (1H, s, N-H), 7.67 (2H, d, $J=8.4$ Hz, H-2/H-6 Ph), $7.06(2 \mathrm{H}, \mathrm{d}, J=8.4 \mathrm{~Hz}, \mathrm{H}-3 / \mathrm{H}-5 \mathrm{Ph}), 6.58$ (1H, s, H-5 Pyrim), $2.47(2 \mathrm{H}, \mathrm{t}, J=7.5 \mathrm{~Hz}, \mathrm{H}-6), 2.29(6 \mathrm{H}, \mathrm{s}, 2 \times \mathrm{Me}), 2.19(2 \mathrm{H}, \mathrm{t}, J=$ $7.3 \mathrm{~Hz}, \mathrm{H}-2), 1.52$ (4H, m, H-3 and H-5), $1.28(2 \mathrm{H}, \mathrm{m}, \mathrm{H}-4) ;{ }^{13} \mathrm{C}$ ${ }_{5} \mathrm{NMR}\left(75 \mathrm{MHz}, \mathrm{DMSO}-\mathrm{d}_{6}\right) \delta(\mathrm{ppm}) 174.4(\mathrm{C}-1), 166.8(\mathrm{C}-4$ and C-6 Pyrim), 159.7 (C-2 Pyrim), 138.5 (C-4 Ph), 134.5 (C-1 Ph), 128.1 (C-3/C-5 Ph), 118.5 (C-2/C-6 Ph), 110.6 (C-5 Pyrim), 34.3 (C-6), 33.6 (C-2), 30.8 (C-5), 28.1 (C-4), 24.3 (C-3), 23.4 $(2 \times \mathrm{Me}) ; \mathrm{IR}(\mathrm{KBr}) v_{\max } / \mathrm{cm}^{-1} 3295,3202,3125,3082,2918,2847$, $101698,1618,1585,1547,1410,1377,1274,842,733,634,547$, 504; MS (EI, 70 eV) m/z (\%) 313 (M+, 45), 312 (9), 238 (3), 226 (5), 213 (7), 212 (100), 211 (4); HRMS, $m / z$ required for $\mathrm{C}_{18} \mathrm{H}_{23} \mathrm{~N}_{3} \mathrm{O}_{2}$ 313.17903, found 313.17896.

Hapten activation was readily performed using DSC, and the 15 corresponding $N$-succinimidyl ester was easily purified. Briefly, hapten PMp6 (3, $32.1 \mathrm{mg}, 0.102 \mathrm{mmol})$ and DSC (34 mg, 0.133 mmol, 1.3 equiv.) were dissolved in dry $\mathrm{CH}_{3} \mathrm{CN}(1 \mathrm{~mL})$ under nitrogen atmosphere. Next, $\mathrm{Et}_{3} \mathrm{~N}(54 \mu \mathrm{L}, 0.387 \mathrm{mmol}, 3.8$ equiv.) was added and the reaction mixture was stirred at $\mathrm{rt}$ for $15 \mathrm{~h}$. The 20 solution was diluted with chloroform, washed with an aqueous saturated solution of $\mathrm{NaHCO}_{3}$ and brine and then dried over anhydrous $\mathrm{Na}_{2} \mathrm{SO}_{4}$. Flash column chromatography of the residue that was left after evaporation of the solvent, using chloroform as eluent, gave the pure $N$-succinimidyl ester of hapten PMp6 (4, 34 $25 \mathrm{mg}, 82 \%)$ as an oil. ${ }^{1} \mathrm{H}$ NMR $\left(300 \mathrm{MHz}, \mathrm{C}_{6} \mathrm{D}_{6}\right) \delta(\mathrm{ppm}) 7.64(2 \mathrm{H}$, d, $J=8.3 \mathrm{~Hz}, \mathrm{H}-2 / \mathrm{H}-6 \mathrm{Ph}), 7.31(1 \mathrm{H}, \mathrm{s}, \mathrm{N}-\mathrm{H}), 7.00(2 \mathrm{H}, \mathrm{d}, J=$ $8.3 \mathrm{~Hz}, \mathrm{H}-3 / \mathrm{H}-5 \mathrm{Ph}), 5.95$ (1H, s, H-5 Pyrim), 2.34 (2H, t, $J=7.6$ $\mathrm{Hz}, \mathrm{H}-6), 2.10(6 \mathrm{H}, \mathrm{s}, 2 \times \mathrm{Me}), 2.08(2 \mathrm{H}, \mathrm{t}, J=7.6 \mathrm{~Hz}, \mathrm{H}-2), 1.58$ $\left(4 \mathrm{H}\right.$, br s, $\left.\mathrm{COCH}_{2} \mathrm{CH}_{2} \mathrm{CO}\right), 1.40(2 \mathrm{H}, \mathrm{m}, \mathrm{H}-5), 1.31(2 \mathrm{H}, \mathrm{m}, \mathrm{H}-3)$, $301.05(2 \mathrm{H}, \mathrm{m}, \mathrm{H}-4) ;{ }^{13} \mathrm{C}$ NMR $\left(75 \mathrm{MHz}, \mathrm{C}_{6} \mathrm{D}_{6}\right) \delta(\mathrm{ppm}) 169.1(\mathrm{C}-$ 1), 168.9 (CONHCO), 167.4 (C-4 and C-6 Pyrim), 160.7 (C-2 Pyrim), 138.6 (C-4 Ph), 135.5 (C-1 Ph), 128.9 (C-3/C-5 Ph), 119.5 (C-2/C-6 Ph), 111.3 (C-5 Pyrim), 35.2 (C-6), 31.2(C-2), 30.9 (C-5), $28.4(\mathrm{C}-4), 25.3\left(\mathrm{COCH}_{2} \mathrm{CH}_{2} \mathrm{CO}\right) 24.6$ (C-3), 23.8 $35(2 \times \mathrm{Me})$.

\section{Conjugate preparation}

Immunizing conjugates were prepared using BSA as carrier, whereas OVA and HRP were employed in the preparation of competing antigens for indirect and direct assays, respectively. ${ }_{40}$ Conjugation was performed with gentle stirring in amber glass vials. Conjugates were purified by size exclusion chromatography using 3 serially-connected HiTrap columns and PB as eluent, and they were stored frozen at $-20^{\circ} \mathrm{C}$. The degree of conjugation was estimated from absorbance measurements at $280 \mathrm{~nm}$ of the

45 conjugate assuming that the molar absorptions of both, the hapten and the protein, did not change upon conjugation.

To prepare BSA-PMp6 conjugate, $200 \mu \mathrm{L}$ of a $50 \mathrm{mM}$ solution of the $N$-succinimidyl ester of PMp6 (4) in anhydrous DMF was added drop wise over a $15 \mathrm{mg} \mathrm{mL}^{-1}$ BSA solution (2 $50 \mathrm{~mL}$ ) in $\mathrm{CB}$ and the mixture was gently stirred at $\mathrm{rt}$ during $4 \mathrm{~h}$. After purification, the collected volume was brought to $30 \mathrm{~mL}$ with PB.

As coating antigens, three OVA conjugates were prepared with different MRs. One hundred microlitres of a solution containing 5510,5 or $1 \mu \mathrm{mol}$ of activated PMp6 (4) in DMF was slowly added over a $2 \mathrm{~mL}$ OVA solution $\left(15 \mathrm{mg} \mathrm{mL}^{-1}\right)$ in $\mathrm{CB}$ under stirring. The mixture was reacted during $2.5 \mathrm{~h}$ at $\mathrm{rt}$ and the conjugate was purified as described above. The pooled fractions containing the conjugate were brought to $30 \mathrm{~mL}$ using $\mathrm{PB}$ and stored frozen at $60-20{ }^{\circ} \mathrm{C}$.

For direct assays, two tracer conjugates were prepared with different MRs. The same conjugation procedure as for the OVA conjugates was followed, except that a $1.0 \mathrm{~mL}$ HRP solution $(2.2$ $\mathrm{mg} \mathrm{mL}{ }^{-1}$ ) was employed and 1 or $0.5 \mu \mathrm{mol}$ of activated PMp6 (4) ${ }_{65}$ in $100 \mu \mathrm{L}$ of DMF was added.

\section{Antibody generation}

Animal manipulation was carried out in compliance with Spanish laws and guidelines (RD1201/2005 and law 32/2007) and according to European Directive 2010/63/EU concerning 70 protection of animals used for scientific purposes. Two female New Zealand white rabbits were immunized following standard protocols as described in previous publications. ${ }^{22}$ Briefly, $0.3 \mathrm{mg}$ of BSA-PMp6 conjugate in $1 \mathrm{~mL}$ of a 1:1 mixture of $\mathrm{PB}$ and complete (for first dose) or incomplete (for additional doses)

75 Freund's adjuvant was used as immunogen. Animals were boosted three times at 21-day intervals. Whole blood was collected from the ear vein of the rabbits and by intracardiac puncture 10 days after the fourth injection. Blood samples were allowed to coagulate overnight at $4{ }^{\circ} \mathrm{C}$. Then, the serum was 80 separated by centrifugation and antibodies were precipitated twice with a solution of saturated ammonium sulphate. Precipitates were stored at $4{ }^{\circ} \mathrm{C}$.

\section{Conjugate-coated indirect competitive assays}

Coating was performed with $100 \mu \mathrm{L}$ per well of OVA conjugate 85 solution in CB by overnight incubation at rt. Each microwell was washed four times with washing solution and received, afterwards, $50 \mu \mathrm{L}$ of pyrimethanil standard solution in PBS plus $50 \mu \mathrm{L}$ of antibody dilution in PBST. The reaction was allowed to reach equilibrium $(1 \mathrm{~h})$ and plates were washed again. Next, 100 ${ }_{90} \mu \mathrm{L}$ per well of a $10^{4}$-fold dilution of GAR-HRP conjugate in PBST containing $10 \%$ FBS was added, and plates were incubated $1 \mathrm{~h}$ at $\mathrm{rt}$. Signal was produced by addition of $100 \mu \mathrm{L}$ per well of freshly prepared $2 \mathrm{mg} \mathrm{mL} \mathrm{mL}^{-1} o$-phenylenediamine solution containing $0.012 \%(\mathrm{v} / \mathrm{v}) \mathrm{H}_{2} \mathrm{O}_{2}$ in substrate buffer. The enzymatic 95 reaction was stopped after $10 \mathrm{~min}$ at $\mathrm{rt}$ with $100 \mu \mathrm{L}$ per well of $2.5 \mathrm{M}$ sulphuric acid. The absorbance was immediately read at $492 \mathrm{~nm}$ with a reference wavelength at $650 \mathrm{~nm}$.

\section{Antibody-coated direct competitive assays}

Plates were coated overnight at rt with $100 \mu \mathrm{L}$ per well of 100 antibody dilution in CB. After washing as described above, $50 \mu \mathrm{L}$ of analyte standard solution in PBS plus $50 \mu \mathrm{L}$ of HRP-PMp6 tracer conjugate in PBST were added to each well. The immunological reaction was run during $1 \mathrm{~h}$ at $\mathrm{rt}$, and then plates were washed as usually. Signal was developed and read as 105 explained for the previous format.

\section{One-step and two-step capture-antibody direct competitive} assays

Coating was done by overnight incubation at rt with $100 \mu \mathrm{L}$ per well of a $1 \mu \mathrm{g} \mathrm{mL}^{-1}$ solution of GAR in CB. After each step, 110 microwells were washed four times with washing solution. These assays were performed at rt following either a one-step or a twostep procedure. If the assay was performed in two steps, a $100 \mu \mathrm{L}$ dilution of primary antibody in PBST was employed and, after 
washing, the competitive reaction was done as described for the previous direct assay. In one-step assays, each microwell received sequentially the three reagents: first, $50 \mu \mathrm{L}$ of pyrimethanil standard solution in PBS; second, $25 \mu \mathrm{L}$ of tracer conjugate in ${ }_{5}$ PBST; and third, $25 \mu \mathrm{L}$ of antibody dilution in PBST. Signal was developed and read as in other ELISA formats.

\section{Solvent, pH and ionic strength studies}

Pyrimethanil standard curves were prepared in Milli-Q water containing between 0.5 and $10 \%(\mathrm{v} / \mathrm{v})$ methanol, ethanol or 10 acetonitrile, and immunoreagents were prepared in $2 \times \mathrm{PBS}$ containing $0.05 \%(\mathrm{v} / \mathrm{v})$ Tween 20 . The influence of buffer ionic strength and $\mathrm{pH}$ was evaluated at $\mathrm{rt}$ following a central composite design that involved a total of 39 randomized buffer studies. The ionic strength values of the evaluated buffers ranged between 50 15 and $300 \mathrm{mM}$, and the studied $\mathrm{pH}$ values were between 5.5 and 9.5. Buffers were prepared from a $40 \mathrm{mM}$ trisodium citrate, 40 $\mathrm{mM}$ disodium hydrogen phosphate and $40 \mathrm{mM}$ Tris solution as previously published, ${ }^{23}$ so three buffer systems were enclosed (citrate, $\mathrm{pKa}_{2}=4.8$ and $\mathrm{pKa}_{3}=6.4$; phosphate, $\mathrm{pKa}_{2}=7.2$; and ${ }_{20}$ Tris, $\mathrm{pKa}=8.1$ ) with buffering capacities covering the whole range of assayed $\mathrm{pH}$ values. $\mathrm{NaCl}$ was employed to adjust the ionic strength in each case. Pyrimethanil standards were run in Milli-Q water and enzyme tracer solutions were prepared in each of the studied buffers containing $0.05 \%(\mathrm{v} / \mathrm{v})$ Tween 20. Curve

25 parameters were fitted, by a multiple regression equation, with the assayed $\mathrm{pH}$ and ionic strength values of the buffer using Minitab 14.1 software (Minitab Inc., State College, PA, USA).

\section{Standard curve and data processing}

Eight-point standard curves, including a blank (no analyte), were 30 prepared by 10 -fold serial dilution in PBS from a $4 \mathrm{mg} \mathrm{mL}$ pyrimethanil stock solution in anhydrous DMF. Experimental values were fitted to a four-parameter logistic equation using the SigmaPlot software package from SPSS Inc. (Chicago, IL, USA). Assay sensitivity was defined as the concentration of analyte 35 affording a $50 \%$ inhibition $\left(\mathrm{IC}_{50}\right)$ of the maximum absorbance $\left(\mathrm{A}_{\max }\right)$ reached in the absence of analyte. Cross-reactivity (CR) was determined as the percentage value from the quotient between the $\mathrm{IC}_{50}$ value for pyrimethanil and the $\mathrm{IC}_{50}$ value for the corresponding analyte, both in molar concentration units.

\section{${ }_{40}$ Sample analysis}

Commercial carrot juice was directly spiked using a pyrimethanil stock solution in DMF. Before ELISA, samples were properly diluted with Milli-Q water.

\section{Results and discussion}

\section{${ }_{45}$ Immunoreagent production}

Synthesis of hapten PMp6 (3) involved the aromatic nucleophilic substitution reaction of 4,6-dimethylpyrimidine (1) with 6-(4-aminopheny)hexanoic acid (2), which occurred quite efficiently, without necessity of either acid o basic catalyst, by 50 simple heating of both reactants in 1,4-dioxane at reflux (Fig. 2). Also, activation of the carboxyl moiety of hapten PMp6 (3) was easily achieved using DSC, a procedure that allowed us to obtain the $N$-succinimidyl ester derivative of the hapten, i.e. compound 4, in high yield and purity.

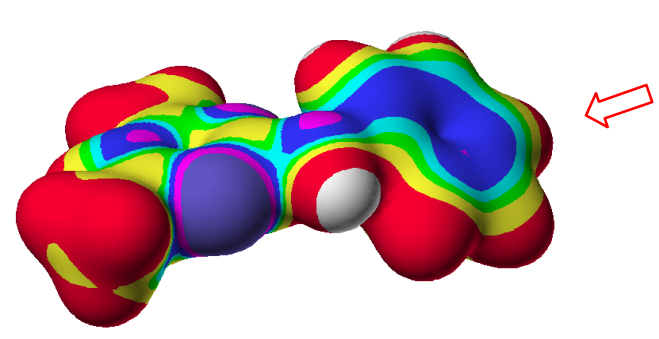

Fig. 3. Electron density isosurface colored by electrostatic potential of the most stable conformation of pyrimethanil. The energy values [in atomic units $(\mathrm{au})]$ at each color interface are: white-red, $+0.09 \mathrm{au}$; red-yellow, +0.02 au; yellow-green, +0.01 au; green-light blue, 0.00 au; light blue-dark blue, -0.01 au; dark blue-pink, -0.03 au; pink-violet, $-0.06 \mathrm{au}$; where $1 \mathrm{au}=627.503 \mathrm{kcal} / \mathrm{mol}$. Arrow indicates the spacer attachment site in hapten PMp6.

55 A conformational analysis of pyrimethanil showed that it exists in a rapid equilibrium between several energetically similar extended conformations, all of them displaying a very small angle between the planes formed by the two aromatic rings. The $3 \mathrm{D}$ spatial representation of the electrostatic potential surface of the 60 most stable conformation $(43.818 \mathrm{kcal} / \mathrm{mol})$ shows the nearly planar disposition of the molecular framework and electron density distribution, which evidences the concentration of negative charge density on the nearest surrounding of the nitrogen atoms (Fig. 3). The prepared hapten (PMp6) preserves 65 the complete skeleton of pyrimethanil, and no or little conformational or electronic alterations of the parent pyrimethanil framework could be reasonably expected. Moreover, optimal display of the relevant immunogenic moieties of this anilinopyrimidine is favored because of the distal position 70 of the spacer arm with respect to the pyrimidine ring.

The availability of the activated hapten in purified form allowed us to readily prepare both the immunizing and the assay conjugates using the same coupling procedure. With such hapten activation strategy, conjugates to OVA and HRP with precise 75 hapten-to-protein ratios could be readily prepared. MRs were estimated after conjugate purification considering a molar extinction coefficient for hapten PMp6 of $14.9 \mathrm{mM}^{-1} \mathrm{~cm}^{-1}$ (determined at $280 \mathrm{~nm}$ in $\mathrm{PB}$ ). The calculated $\mathrm{MR}$ of the immunogen was 13; those of the three OVA conjugates were 2, 4 80 and 7; and those of the two tracer conjugates were 2 and 3.

Two polyclonal antibodies, namely rPMp6\#1 and rPMp6\#2, were generated with BSA-PMp6 as immunizing conjugate. A standard immunization process was applied, so whole blood was collected 2.5 months after the first injection. Antibodies were ${ }_{85}$ used in a partially purified form, i.e. first, antisera were separated by centrifugation and then, immunoglobulins were precipitated by salting out. The selectivity of the generated antibodies was checked by direct competitive homologous assays using as competitors (up to $10 \mu \mathrm{M}$ ) the two other anilinopyrimidine 90 fungicides (cyprodinil and mepanipyrim). It was found that antibody rPMp6\#1 was selective of pyrimethanil (CR $<0.1 \%$ for cyprodinil and mepanipyrim), whereas antibody rPMp6\#2 showed a higher recognition of cyprodinil $(\mathrm{CR}=21 \%)$ and mepanipyrim $(\mathrm{CR}=5 \%)$. Other common agrochemicals 95 (azoxystrobin, fenhexamid and boscalid) were also tested and they were not bound by any of the two antibodies. Despite the great molecular structure similarity of the three members of this 
Table 1 Curve parameters for conjugate-coated indirect competitive assays $(n=3)$

\begin{tabular}{|c|c|c|c|c|c|c|c|c|c|}
\hline \multirow{2}{*}{\multicolumn{2}{|c|}{ OVA-PMp6 }} & \multicolumn{8}{|c|}{ Antibody } \\
\hline & & \multicolumn{4}{|c|}{ rPMp6\#1 } & \multicolumn{4}{|c|}{ rPMp6\#2 } \\
\hline MR & Conc. (ng mL $\left.{ }^{-1}\right)^{a}$ & Dil. $^{b}$ & $\mathrm{~A}_{\max }$ & Slope & $\mathrm{IC}_{50}\left(\mathrm{ng} \mathrm{mL} \mathrm{mL}^{-1}\right)$ & Dil. & $\mathrm{A}_{\max }$ & Slope & $\mathrm{IC}_{50}\left(\mathrm{ng} \mathrm{mL} \mathrm{L}^{-1}\right)$ \\
\hline \multirow[t]{3}{*}{7} & 1000 & n.a. ${ }^{\mathrm{c}}$ & & & & n.a. & & & \\
\hline & 100 & $3 \times 10^{5}$ & 0.93 & -0.49 & 8.4 & $1 \times 10^{6}$ & 0.96 & -0.47 & 7.9 \\
\hline & 10 & $3 \times 10^{4}$ & 1.29 & -0.53 & 6.2 & $1 \times 10^{5}$ & 1.25 & -0.55 & 5.8 \\
\hline \multirow[t]{3}{*}{4} & 1000 & $3 \times 10^{5}$ & 1.54 & $--^{d}$ & --- & $1 \times 10^{6}$ & 0.96 & --- & -- \\
\hline & 100 & $3 \times 10^{5}$ & 1.03 & -0.47 & 8.6 & $1 \times 10^{6}$ & 1.01 & -0.55 & 9.6 \\
\hline & 10 & $3 \times 10^{4}$ & 1.39 & -0.54 & 5.8 & $1 \times 10^{5}$ & 1.40 & -0.54 & 6.3 \\
\hline \multirow[t]{3}{*}{2} & 1000 & $3 \times 10^{5}$ & 1.35 & --- & -- & $1 \times 10^{6}$ & 1.25 & --- & --- \\
\hline & 100 & $1 \times 10^{5}$ & 1.12 & -0.56 & 2.8 & $3 \times 10^{5}$ & 1.09 & -0.57 & 4.5 \\
\hline & 10 & $1 \times 10^{4}$ & 0.56 & -0.61 & 6.2 & $1 \times 10^{4}$ & 0.94 & -0.58 & 8.5 \\
\hline
\end{tabular}

family (Fig. 1), one highly selective antibody was obtained. Since metabolism of pyrimethanil in plants is negligible ${ }^{13}$ and the antibody is highly specific, accurate measurements and no interferences from degradation products can be expected in 5 vegetable analysis. However, results would be more uncertain with animal or environmental samples because metabolites and degradation products can exist. ${ }^{13}$

\section{Immunoassay characterization}

Four sorts of ELISA formats were studied using a checkerboard 10 competitive approach in which a pyrimethanil standard curve (from $0.002 \mathrm{ng} \mathrm{mL}^{-1}$ to $2000 \mathrm{ng} \mathrm{mL}$ plus a blank) was run in each plate column, and different concentrations of the involved immunoreagents were simultaneously evaluated in triplicate wells. unspecific binding events were not noticed. It was seen that the two generated antibodies displayed high affinity to pyrimethanil. Also, as revealed from the results listed in Table 1 , the $\mathrm{IC}_{50}$ values of indirect assays could be improved by lowering either 30 the coating conjugate concentration or the conjugate MR.

\section{Direct assays}

Checkerboard competitive studies were run in the direct ELISA format with plates coated using different antibody dilutions (from $10^{4}$ to $2 \times 10^{5}$ fold), and with solutions of varying concentrations 35 of HRP-PMp6 (from 3 to $10 \mathrm{ng} \mathrm{mL}{ }^{-1}$ ). In addition, two tracers with different MRs were assayed. The parameters of the inhibition curve with the $\mathrm{A}_{\max }$ closest to 1.0 for each immunoreagent combination are listed in Table 2. As before, those curves showed near zero signals (around 0.01) under 40 complete inhibition conditions. Lower $\mathrm{IC}_{50}$ values were found

$\underline{\text { Table } 2 \text { Curve parameters for antibody-coated direct competitive assays }(n=3)}$

\begin{tabular}{|c|c|c|c|c|c|c|c|c|c|}
\hline \multirow{2}{*}{\multicolumn{2}{|c|}{ HRP-PMp6 }} & \multicolumn{8}{|c|}{ Antibody } \\
\hline & & \multicolumn{4}{|c|}{ rPMp6\#1 } & \multicolumn{4}{|c|}{ rPMp6\#2 } \\
\hline MR & Conc. (ng mL $\left.{ }^{-1}\right)^{\mathrm{a}}$ & Dil. $^{b}$ & $A_{\max }$ & Slope & $\mathrm{IC}_{50}\left(\mathrm{ng} \mathrm{mL} \mathrm{m}^{-1}\right)$ & Dil. & $\mathrm{A}_{\max }$ & Slope & $\mathrm{IC}_{50}\left(\mathrm{ng} \mathrm{mL}^{-1}\right)$ \\
\hline \multirow[t]{3}{*}{3} & 10 & $5 \times 10^{4}$ & 0.98 & -0.72 & 3.5 & $2 \times 10^{5}$ & 1.09 & -0.79 & 9.8 \\
\hline & 5 & $3 \times 10^{4}$ & 1.10 & -0.73 & 2.6 & $2 \times 10^{5}$ & 0.82 & -0.80 & 6.0 \\
\hline & 3 & $2 \times 10^{4}$ & 1.17 & -0.70 & 5.6 & $1 \times 10^{5}$ & 1.14 & -0.68 & 4.7 \\
\hline \multirow[t]{3}{*}{2} & 10 & $5 \times 10^{4}$ & 0.87 & -0.75 & 3.2 & $2 \times 10^{5}$ & 0.87 & -0.80 & 6.9 \\
\hline & 5 & $3 \times 10^{4}$ & 0.97 & -0.76 & 2.4 & $1 \times 10^{5}$ & 1.24 & -0.70 & 3.8 \\
\hline & 3 & $2 \times 10^{4}$ & 1.01 & -0.70 & 2.3 & $1 \times 10^{5}$ & 0.93 & -0.74 & 3.5 \\
\hline
\end{tabular}

\section{Indirect assays}

OVA-PMp6 conjugates with different MRs were employed for coating using solutions at three alternative concentrations (10, 100 and $1000 \mathrm{ng} \mathrm{mL}^{-1}$ ), and six antibody dilutions were assayed ranging from $10^{4}$ to $3 \times 10^{6}$ fold. Thus, a series of inhibition curves 20 were obtained for each immunoreagent pair, from which the curve with an $\mathrm{A}_{\max }$ value nearest to 1.0 was picked out. The main parameters of selected curves for each antibody-conjugate combination are listed in Table 1. As it can be observed, low slopes (below -0.6$)$ were generally found. Signals at excess of 25 analyte $\left(2000 \mathrm{ng} \mathrm{mL}^{-1}\right)$ were always below $10 \%$ of the $\mathrm{A}_{\max }$, so with antibody rPMp6\#1, and a balance had to be reached between antibody and tracer concentrations in order to achieve the highest detectability. Compared to indirect assays, higher slopes (over -0.7 in most cases) and slightly better $\mathrm{IC}_{50}$ values were attained 45 with this ELISA format. On the contrary, a lower MR of the enzyme conjugate did not show a clear influence over the sensitivity of the immunoassay.

\section{Capture-antibody assays}

Two additional competitive ELISA formats were evaluated using 50 plates coated with a capture antibody specific of rabbit IgG $(\mathrm{H}+\mathrm{L})$. Assays were carried out in a one-step (antibody + tracer +

Table 3 Curve parameters for direct competitive assays using capture antibody and antibody rPMp6\#1 $(n=3)$

\begin{tabular}{|c|c|c|c|c|c|c|c|c|}
\hline \multirow{3}{*}{$\begin{array}{c}\text { HRP-PMp6 } \\
\text { Conc. }\left(\text { ng mL }{ }^{-1}\right)^{\mathrm{a}}\end{array}$} & \multicolumn{8}{|c|}{ Assay procedure } \\
\hline & \multicolumn{4}{|c|}{ Two-step assay } & \multicolumn{4}{|c|}{ One-step assay } \\
\hline & Dil. $^{b}$ & $\mathrm{~A}_{\max }$ & Slope & $\mathrm{IC}_{50}\left(\mathrm{ng} \mathrm{mL}^{-1}\right)$ & Dil. & $\mathrm{A}_{\max }$ & Slope & $\mathrm{IC}_{50}\left(\mathrm{ng} \mathrm{mL}^{-1}\right)$ \\
\hline 10 & $1 \times 10^{5}$ & 1.16 & -0.62 & 2.1 & $1 \times 10^{5}$ & 1.44 & -0.65 & 1.7 \\
\hline 5 & $1 \times 10^{5}$ & 0.89 & -0.63 & 1.1 & $1 \times 10^{5}$ & 0.91 & -0.66 & 1.3 \\
\hline 3 & $5 \times 10^{4}$ & 0.92 & -0.62 & 1.1 & $5 \times 10^{4}$ & 0.54 & -0.73 & 3.6 \\
\hline
\end{tabular}




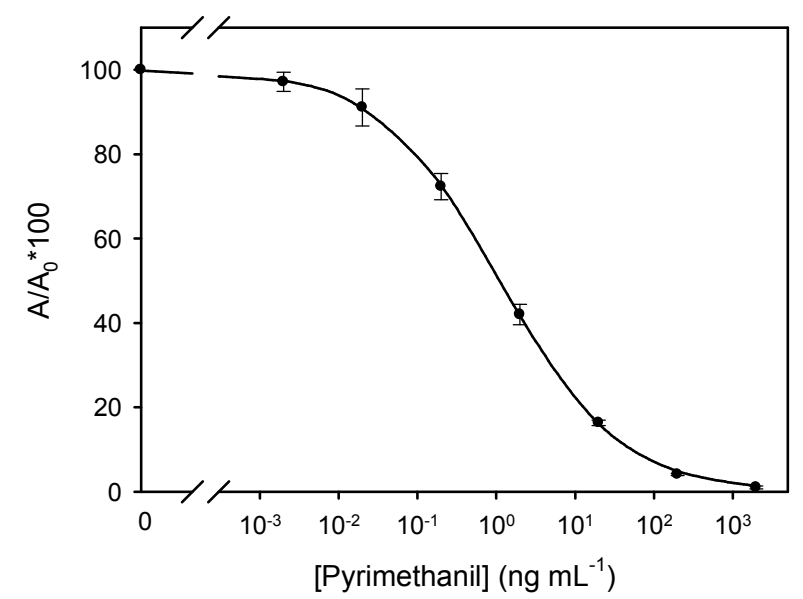

Fig. 4. Assay standard curve using the two-step capture direct ELISA format. Values are the mean of eight independent determinations. The mean $\mathrm{A}_{\max }$ value was 0.82. Antibody rPMp6\#1 was diluted $10^{5}$ fold and the optimum assay concentration of HRP-PMp6 was $5 \mathrm{ng} \mathrm{mL}^{-1}$.

sample) or a two-step mode (plates were washed after the capture reaction). One-step assays were performed with consecutive addition of standard, tracer and antibody solutions - in that order and with no previous incubation of the primary antibody with the 5 analyte or the capture antibody. In two-step assays, 30-min
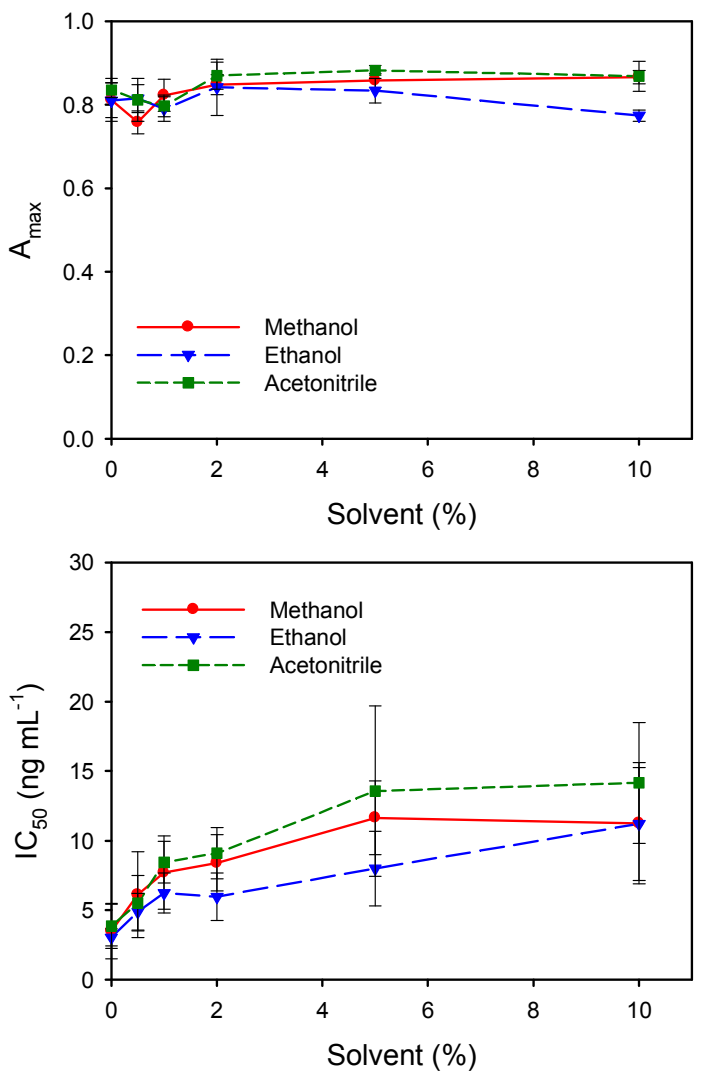

Fig. 5. Variation of $\mathrm{A}_{\max }$ and $\mathrm{IC}_{50}$ values of the two-step capture direct competitive immunoassay with antibody rPMp6\#1 due to the presence of organic solvents in the reaction mixture. incubation time was found to be sufficient for the capture step to reach equilibrium. Again, checkerboard competitive assays were carried out using different concentrations of primary antibody $(\mathrm{rPMp} 6 \# 1)$ and tracer conjugate $(\mathrm{MR}=2)$ in the presence of a 10 standard curve of pyrimethanil. Both capture-assay formats (onestep or two-step) gave equivalent results (Table 3). Curve slopes between -0.6 and -0.7 were obtained, and near zero signals were always found at high analyte concentrations. The lowest $\mathrm{IC}_{50}$ value $\left(1.1 \mathrm{ng} \mathrm{mL}^{-1}\right)$ was achieved with the two-step assay. That 15 immunoassay, the standard curve of which can be seen in Fig. 4, afforded a limit of detection $\left(\mathrm{IC}_{10}\right)$ of $0.024 \mathrm{ng} \mathrm{mL} \mathrm{m}^{-1}$, so it was selected for further characterization.

\section{Influence of solvents and buffer conditions}

The selected two-step capture-antibody direct competitive ELISA 20 using rPMp6\#1 as specific antibody for pyrimethanil and the tracer conjugate with $\mathrm{MR}=2$, as described in Fig. 4, was employed in these studies. Influence of solvent contents (from $0.5 \%$ to $10 \%$ ) over the $\mathrm{A}_{\max }$ and $\mathrm{IC}_{50}$ values of the standard curve was investigated. Three solvents (methanol, ethanol and 25 acetonitrile) which are commonly employed for direct pesticide extraction or in the QuEChERS technique ${ }^{24}$ were evaluated. As shown in Fig. 5, those solvents were quite well tolerated in the studied solvent concentration range, since up to $10 \%(\mathrm{v} / \mathrm{v})$ solvent contents did not modify the maximum signal and just 3-fold 30 higher $\mathrm{IC}_{50}$ values were obtained.
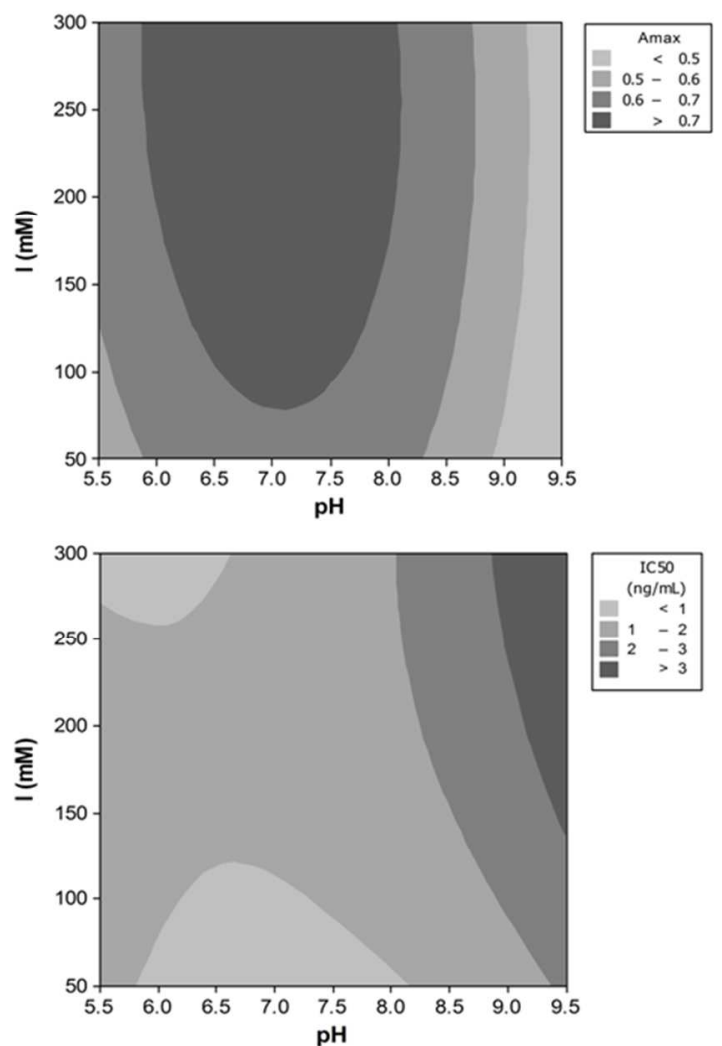

Fig. 6. Influence of buffer conditions over the $A_{\max }$ and $\mathrm{IC}_{50}$ values of the standard curve of the selected assay. Contour plots were obtained by a central composite design, taking PBST as the centre point, and consisting of a 2-level full factorial design $(\alpha=$ 1.414) with 2 factors and 3 replicates, that included 12 cube, 12 axial and 15 centre point data. 


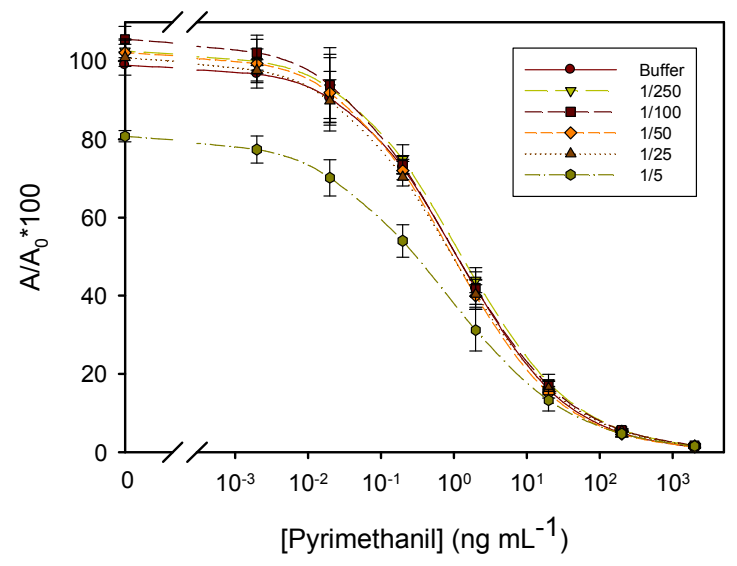

Fig. 7. Matrix effects of carrot juice over the standard curve of the developed capture direct immunoassay for pyrimethanil.

A rigorous approach was applied in order to assess the influence of $\mathrm{pH}$ and ionic strength over the main standard curve parameters. A complex buffer system (citrate-phosphate-Tris) was constructed so as to cover a wide range of $\mathrm{pH}$ values 5 (from5.5 to 9.5). Tween 20 was added to each buffer and the ionic strength was corrected with $\mathrm{NaCl}$ to keep it constant, so only one factor (either the $\mathrm{pH}$ or the ionic strength) changed at a time. Moreover, the employed multiparametric strategy for data treatment with a full factorial design afforded a bidimensional 10 picture showing changes of $\mathrm{A}_{\max }$ and $\mathrm{IC}_{50}$ values as functions of $\mathrm{pH}$ and ionic strength simultaneously (Fig. 6). Thus, it could easily be observed that the selected immunoassay was pretty robust to $\mathrm{pH}$ and ionic strength, and that the highest $\mathrm{A}_{\max }$ and optimum $\mathrm{IC}_{50}$ values were obtained around PBS-equivalent ionic 15 strength $\left(I=162 \mathrm{mM}\right.$ at $\left.25^{\circ} \mathrm{C}\right)$ and neutral $\mathrm{pH}$ conditions; that is, the central point of the applied factorial design.

\section{Pyrimethanil analysis}

Carrot juice was selected as a model commodity to evaluate the applicability of the developed immunoassay. First, pyrimethanil 20 competitive assays were carried out in buffer containing different juice proportions to determine the minimum dilution that was required to minimize matrix effects. As seen in Fig. 7, the standard curve that was run in 50 -fold diluted carrot juice was nearly indistinguishable from that run in buffer. Accordingly,

25 recovery studies were undertaken with the developed ELISA by analyzing carrot juice samples spiked with known concentrations of pyrimethanil. As seen in Table 4, this competitive ELISA could measure pyrimethanil from 0.04 to $4 \mu \mathrm{g} \mathrm{mL}^{-1}$ in carrot juice, thus showing a limit of quantification comparable to those 30 reported for GC/MS and HPLC/UV. ${ }^{17}$

Table 4 Pyrimethanil recovery values from spiked carrot juice

\begin{tabular}{cccc}
\hline $\begin{array}{c}\text { Spiked level } \\
\left(\mathrm{ng} \mathrm{mL}^{-1}\right)\end{array}$ & $\begin{array}{c}\text { Concentration } \\
\left(\mathrm{ng} \mathrm{mL}^{-1}\right)\end{array}$ & Recovery (\%) & $\mathrm{CV}(\%)$ \\
\hline 10 & $--\mathrm{b}^{\mathrm{b}}$ & --- & --- \\
40 & 42.5 & 106.3 & 28.2 \\
100 & 104.3 & 104.3 & 14.5 \\
400 & 298.6 & 74.6 & 1.9 \\
1000 & 899.3 & 89.9 & 21.5 \\
4000 & 3929.4 & 98.2 & 20.3 \\
a Samples (n $=2)$ were diluted 50-fold in Milli-Q water before being \\
analyzed, and the tracer conjugate was prepared in $2 \times \mathrm{PBS}$ \\
containing 0.05\% (v/v) Tween 20. ${ }^{\mathrm{b}}$ Out of range. \\
\hline
\end{tabular}

\section{Conclusions}

Pyrimethanil residues are commonly found in environmental and food samples, so development of innovative analytical approaches is demanded. In this study, the first specific 35 antibodies and bioconjugates to this pesticide have been produced and immunoassays have been developed for pyrimethanil bioanalysis in the low nanogram per millilitre range. It was shown that lower hapten-to-protein ratios can help to improve assay detectability in indirect format ELISAs. Purification of the 40 activated hapten allowed us to employ the same protein coupling strategy for immunizing and assay conjugates with no impact on background signals commonly found with polyclonal antibodies. Slopes at the inflection point of standard curves were slightly steeper with direct format assays. The selected ELISA in the 45 capture-antibody direct assay format with a two-step procedure was characterized, and it was applied to the analysis of fortified samples. The achieved limits of detection and quantification were comparable to those of instrumental methodologies. These immunoreagents and ELISAs could contribute to a wider spread 50 of immunochemical assays as alternative and complementary approaches to modern analytical challenges. Based on the excellent immune response triggered by the synthesized hapten, work is in progress with the aim of generating monoclonal antibodies exhibiting even better analytical properties.

\section{${ }_{55}$ Acknowledgements}

This work was supported by the Spanish Ministerio de Ciencia e Innovación (AGL2009-12940-C02-01-02/ALI) and cofinanced by FEDER funds. J.V.M. and F.A.E.-T. were hired by the Consejo Superior de Investigaciones Cientificas (CSIC), the 60 former under a Ramón y Cajal contract and the latter under a $J A E-d o c$ contract, both of them financed by Ministerio de Ciencia $e$ Innovación and the European Social Fund. We thank Ana Izquierdo-Gil and Laura López-Sánchez for excellent technical assistance.

\section{${ }_{65}$ Notes and references}

${ }^{a}$ Institute of Agrochemistry and Food Technology, Consejo Superior de Investigaciones Cientificas (IATA-CSIC), Agusti Escardino 7, 46980 Paterna, València, Spain. Fax: +34-963636301; Tel: +34-963900022; E-mail:aabad@iata.csic.es

$70^{b}$ Department of Organic Chemistry, Universitat de València, Doctor Moliner 50, 46100 Burjassot, València, Spain. Fax: +34-963544328; Tel: +34-963544509; E-mail: antonio.abad@uv.es

1 C. Cháfer-Pericás, A. Maquieira and R. Puchades, Trac-Trend. Anal. Chem., 2010, 29, 1038.

2 J. V. Samsonova, A. Cannavan and C. T. Elliott, Crit. Rev. Anal. Chem., 2012, 42, 50.

3 D. Calvo, N. Tort, J. P. Salvador, M. P. Marco, F. Centi and S. Marco, Analyst, 2011, 136, 4045.

804 D. Z. Souza, P. O. Boehl, E. Comiran, D. S. Prusch, I. Zancanaro, A. M. Fuentefria, F. Pechansky, P. C. A. V. Duarte, R. B. De Boni, P. E. Froehlich and R. P. Limberger, Ther. Drug Monit., 2012, 34, 98.

5 I. Y. Goryacheva, T. Y. Rusanova and N. A. Burmistrova, $J$ Anal. Chem., 2009, 64, 768.

6 M. Gross, V. Curtui, Y. Ackermann, H. Latif and E. Usleber, J. Agric. Food Chem., 2011, 59, 12317. 
7 Z. L. Xu, Q. Wang, H. T. Lei, S. A. Eremin, Y. D. Shen, H. Wang, R. C. Beier, J. Y. Yang, K. A. Maksimova and Y. M. Sun, Anal. Chim. Acta, 2011, 708, 123.

8 J. V. Mercader, C. Suárez-Pantaleón, C. Agulló, A. Abad-

5

10 Somovilla and A. Abad-Fuentes, J. Agric. Food Chem., 2008, 56, 2581.

9 M. C. Zhang, Y. Cong, Y. L. Sheng and B. L. Liu, Anal. Biochem., 2010, 406, 24.

10 M. J. Moreno, P. D'Arienzo, J. J. Manclús and A. Montoya, $J$. Environ. Sci. Heal. B, 2011, 46, 509.

11 K. C. Ahn, S. J. Gee, H. J. Tsai, D. Bennett, M. G. Nishioka, A. Blum, E. Fishman and B. D. Hammock, Environ. Sci. Technol., 2009, 43, 7784.

12 L. Kanetis, H. Förster, C. A. Jones, K. A. Borkovich, J. E. Adaskaveg, Phytopathology, 2008, 98, 205.

13 JMPR, 2007. Pesticide residues in Food - 2007. Evaluations, Part I: Residues. FAO Plant Production and Protection Paper 192. Report of the Joint Meeting of the FAO Panel of Experts on Pesticide Residues in Food and the Environment and the WHO Core Assessment Group on Pesticide Residues, Geneva Switzerland, 18-27 September 2007. WHO and FAO, Rome, 2008.

14 European Commission Directive 2009/74/EC, Off. J. Eur. Union, 2006, L-235, 17.

2515 Scientific Report of EFSA. The 2009 European Union Report on Pesticide Residues in Food. EFSA J., 2011, 9 (11), 2430. Available online at: http://www.efsa.europa.eu/en/publications/efsajournal.htm, accessed June 14, 2012.

16 EU pesticides database at: http://ec.europa.eu/sanco pesticides/public/index.cfm, accessed June 14, 2012.

17 JMPR, 2007. Pesticide residues in Food - 2007. FAO Plant Production and Protection Paper 191. Report of the Joint Meeting of the FAO Panel of Experts on Pesticide Residues in Food and the Environment and the WHO Core Assessment Group on Pesticide Residues, Geneva Switzerland, 18-27 September 2007. WHO and FAO, Rome, 2008.

18 J. Cheng, Y. T. Xia, Y. W. Zhou, F. Guo and G. Chen, Anal. Chim. Acta, 2011, 701, 86.

19 D. Eikel and J. Henion, Rapid Commun. Mass Sp., 2011, 25, 2345.

20 Y. W. Zhou, L. T. Han, J. Cheng, F. Guo, X. R. Zhi, H. L. Hu and G. Chen, Anal. Bioanal. Chem., 2011, 399, 1901.

21 C. Suárez-Pantaleón, J. V. Mercader, C. Agulló, A. AbadSomovilla and A. Abad-Fuentes, J. Agric. Food Chem., 2008, 56, 11122.

22 A. Abad-Fuentes, F.A. Esteve-Turrillas, C. Agulló, A. AbadSomovilla and J. V. Mercader, Food Chem., Submitted.

23 J. Parra, J. V. Mercader, C. Agulló, A. Abad-Somovilla and A. Abad-Fuentes, Anal. Chim. Acta, 2012, 715, 105.

24 M. Anastassiades, S. J. Lehotay, D. Štajnbaher and F. J. Schenck, J. AOAC Int., 2003, 86, 412. 